\title{
Law, Social Norms and Welfare as Means of Public Administration: Case Study of Mahalla Institutions in Uzbekistan
}

Rustamjon Urinboyev ${ }^{1}$

\begin{abstract}
Despite numerous challenges, since its independence, Uzbekistan, with the exception of the May 2005 Andijan events, has enjoyed extraordinary political stability and not recorded any considerable cases of interethnic or interfaith conflict, regime change or civil war, whereas neighboring Kyrgyzstan, labeled an "island of democracy" by the Western world, has experienced numerous conflicts and chaos, ranging from "color revolutions" to ethnic conflict. However, for understanding Uzbekistan's ability to cope with internal and external challenges, little recourse is made to the post-independence discourse on public administration known as "mahalla reforms". In spite of the significant existing body of literature on the mahalla, there has been little systematic scholarly investigation of the role of mahalla in maintaining political stability and security in Uzbekistan. Previous studies did not provide an account of how the law, social norms and welfare come to interplay in the mahalla system and how this influences the public administration developments in Uzbekistan. This paper begins to redress this lacuna by analyzing public-administration reforms in post-independence Uzbekistan, namely mahalla reforms, with an effort to show how political and social stability is established through mahalla, and to what extent those reforms have affected the position of individuals vis-à-vis the publicadministration system. In undertaking this task, the paper employs three theoretical concepts: the theory of norms, the welfare-pentagon model and the theory of social control. In this paper, I argue that public-administration reforms since 1991 have transformed mahalla into a comprehensive system of social control; and therefore, mahalla can be places of democratic involvement or sites of authoritarianism in Uzbekistan.
\end{abstract}

Keywords: mahalla; public administration; norms; social control; welfare.

1 PhD Candidate, Department of Sociology of Law, Lund University, Lund, Sweden. 


\section{Introduction}

It was believed that the introduction of the Western-type political institutions of democratic government and market-oriented economy would promote democratic transformations and contribute to the formation of stable nation-states in post-Soviet Central Asia (Gleason 2001). As a newly-independent state with democracy claims, Uzbekistan has proclaimed the creation of a secular democratic society based on the ideals of democracy, free market, social justice and universal human rights ${ }^{2}$ with an effort to capture the international community's attention and attract foreign direct investment. However, like other post-Soviet states, during the early years of independence, Uzbekistan faced the necessity of re-designing its economic and social policies. While struggling to develop market economy, Uzbekistan simultaneously strived to retain a Soviet-type generous social-welfare system, given the unstable political situation in Central Asia during the 1990s. ${ }^{3}$ Uzbekistan has emphasized "stability at any cost" as its main aim in this period, rather than asserting economic growth (Spechler 2000, 295). Given the fact that the former Soviet social-welfare system did provide extensive social-welfare benefits and health-care facilities, the general population of Uzbekistan likely expected the same treatment and facilities from the new Uzbek authorities. Likewise, the main concern of Uzbek authorities in the early years of independence was the prevention of dramatic output loss, strong social protection and modernization of economy through a strengthening of the industrial sector (Ruziev, Ghosh and Dow 2007). The newlyintroduced Uzbek economic development model, which was based on a gradual reform strategy, clearly illustrated this tendency. ${ }^{4}$ In this respect, welfare strategies of the 1990s were, in every sense, a political stability and security project retooled by Uzbek policy-makers to "buy off" the sympathy and loyalty of the general population towards the state; social policy was an effective and legitimate device to extend the coercive power of the state nationwide.

Despite its relatively better performance in the 1990s, Uzbekistan is nowadays facing complex political, economic and social challenges. The level of political liberalizations and economic reform was not sufficient to promote the social welfare of the population, as evidenced by a sharp increase of economic inequality and unemployment in the society. The growing number of Uzbek labor migrants in Russia and Kazakhstan provides clear evidence of the weakening nature of economic and

2 See The Constitution of the Republic of Uzbekistan. arts. 7, 13, 14, 18.

3 The political situation was largely unstable in Central Asia in the 1990s, e.g. ethnic clashes between the Uzbeks and the Meskhetian Turks in 1989, the Osh riots (ethnic conflict between Uzbeks and Kyrgyzs) in 1990, civil war in neighboring Tajikistan in 1992-1997.

4 In his book Uzbekistan on the Way of Deepening Economic Reforms, Islam Karimov, President of Uzbekistan, describes five fundamental principles that form the basis of the Uzbek development model: (i) the precedence of economy over politics; (ii) the leading role of the state during the transition period; (iii) the promotion of the rule of law; (iv) the provision of strong social protection; (v) the gradual and evolutionary transition to a market-based economy. 
social policies. The preservation of a Soviet-type generous social-welfare system appeared to be a fiscally unaffordable task, since the tax revenues were very little compared to the scope of the welfare programs promised by the government. The living standard of ordinary people gradually fell, and the number of people applying for social-welfare benefits grew accordingly. Resource-strapped Uzbekistan had to move away from the Soviet-type generous social policy to a means-tested system. This issue had far-reaching repercussions for the preservation of security and stability in the transition period.

In light of growing social discontent, the provision of security has become a buzzword on the Uzbek policy agenda. The presence of wide police and security forces throughout the country clearly illustrates this tendency. As described by Clarke (1999), Uzbekistan has been trying to maintain a secular state in one of the most religious Muslim countries of the former Soviet Union, while facing the direct threat of political Islam in Afghanistan and Iran. Radical Islam has been growing due to the lack of political liberalization and accumulated economic and social problems. Moreover, the geopolitical positioning of Uzbekistan as the center of the Eurasian "Heartland" 5 and its vast energy resources have attracted international attention and intensified the influence of external powers, such as Russia, the United States, China, Iran and Turkey. All these factors can promote instability and pose immense security threats to Uzbekistan. The existence of a wide variety of internal sources of instability might contribute to the emergence of conflicts in the future. In addition, the growing influence of foreign states and non-state actors might have a negative impact on the security and stability in the country, given the fact that external actors pursue their own agendas and interests. At the same time, local groups and interests might be prone to taking an advantage from the opportunities provided by the presence of external actors. Deteriorating social conditions and a decline in living standards might create an atmosphere of rivalry between different ethnic and religious groups and increase the tensions between them.

Under these circumstances, Uzbekistan should have already fallen into the trap of revolutions, civil war or ethnic conflicts from below. ${ }^{6}$ Domestic and external forces are pulling Uzbekistan into various directions. We can observe the struggle between secular and religious forces on the one hand and democratic and non-democratic forces on the other. The interplay between these forces might have possibly produced three scenarios in Uzbekistan. The first scenario is building an Islamic state based on Shariya law, as the developments since the independence

5 British geographer and politician Sir Halford John Mackinder, one of the founders of geopolitics as a science, called Central Asia the "Heartland" of the world. According to Mackinder, the interests of practically all major world powers collide in Central Asia. He described Central Asia as the political center of the world and predicted whoever controlled it would wield enormous power.

6 For studies of regime change, see, for example, Perry Anderson. 1974. Lineages of the Absolutist State. London: Verson; Alexander Gerschenkron. 1962. Economic Backwardness in Historical Perspective. Cambridge: Harvard University Press; and Barrington Moore Jr. 1966. Social Origins of Dictatorships and Democracy. Boston: Beacon. 
period have shown a growing radicalization of Islam within the society. The second possible scenario is strengthening democracy through building close ties with the Western world. The third scenario is strengthening authoritarianism, which means closer relations with Russia and China.

So far, none of the aforementioned scenarios have entirely occurred in Uzbekistan. Despite numerous challenges, since its independence, Uzbekistan, with the exception of the May 2005 Andijan events, has enjoyed extraordinary political stability and not recorded any considerable cases of interethnic or interfaith conflict, regime change or civil war, whereas neighboring Kyrgyzstan, labeled an "island of democracy" by the Western world, has experienced numerous conflicts and chaos, ranging from "color revolutions" to ethnic conflict. This issue triggered bitter debates within academic and policy communities. Ilkhamov (2007) claims that the Uzbek regime has succeeded in neutralizing internal and external challenges due to its ability to benefit from formal and informal, modern and traditional institutions and practices, the mixture of which constitutes a neopatrimonial authoritarianism. ${ }^{7}$ The findings of Melvin (2000) and Fane (1996) maintain that the Uzbek regime has succeeded in establishing political stability through authoritarian control, policies of repression and stifling the economic reform. Conversely, Spechler $(2000,295)$ asserts that Uzbek authorities guaranteed political stability through subsidizing employment, controlling prices on essential goods and services, privatizing the largest state-owned enterprises only gradually and partially and pursuing self-sufficiency in energy and food supplies. Erdem (2006) explains it by referring to the level of political salience of ethnic groups, namely Tajik minorities; she maintains that ethnicity does not have political significance in Uzbekistan.

There are elements of truth in each of the above-mentioned arguments. However, for understanding Uzbekistan's ability to cope with internal and external challenges, little recourse is made to the post-independence discourse on public administration known as "mahalla reforms". Since mahalla enjoy local legitimacy and informal social safety nets, Uzbek authorities looked at the mahalla as a means for political stability and security. Due to the complexity of internal and external challenges, Uzbekistan deployed traditional mahalla institutions to meet political and social instabilities. In this regard, there has been little systematic scholarly investigation in the role of mahalla in maintaining political stability and security in Uz-

7 Ilkhamov explains Uzbekistan's neopatrimonial regime as a combination of the following mutually supportive factors: (1) hyper-centralization of the administrative system and exceptional control of power assumed by the President; (2) selective adoption of the market economy and the legal administrative system, enabling the ruling elites to legalize resource and capital acquisition; (3) selective use of the legal-administrative system to neutralize open and hidden opposition to the present regime.

8 Mahalla is a traditional community-based organization in Uzbekistan. It is an Arabic word meaning "local community" and alludes to a group of people residing in a specific territory. For simplicity, I use the word "mahalla" to denote both the singular and plural meanings. 
bekistan. ${ }^{9}$ Previous studies have largely illustrated mahalla as instruments of abuse (coercion) and authoritarian control (Abramson 2000a; Human Rights Watch 2003; Kamp 2004; Kassymbekova 2003; Louw 2007; Noori 2006) or as social safety nets (Coudouel and Marnie 1999; Micklewright and Marnie 2005; Sievers 2002). However, those studies did not provide an account of how the law, social norms and welfare come to interplay in the mahalla system and how this influences the publicadministration developments in Uzbekistan. This paper begins to redress this lacuna by analyzing public-administration reforms in post-independence Uzbekistan, namely mahalla reforms, with an effort to show how political and social stability is established through mahalla, and to what extent those reforms have affected the position of individuals vis-à-vis the public-administration system. In undertaking this task, the paper employs three theoretical concepts: the theory of norms, the welfare-pentagon model and the theory of social control. In this paper, I argue that public-administration reforms since 1991 have transformed mahalla into a comprehensive system of social control; and therefore, mahalla can be places of democratic involvement or sites of authoritarianism in Uzbekistan.

\section{Public-administration reforms in the post-independence period: Mahalla reforms}

Until the introduction of the Mahalla Law, mahalla mainly reinforced cooperative relations among the residents through social norms (hereinafter 'mahalla norms'). The introduction of the Mahalla Law led to the fusion of mahalla (social) norms with the law, since most informal functions of the mahalla had become formalized. As a result, mahalla, somewhat traditional informal institutions, have become partly formalized (through legislative codification and executive incorporation), and now partly operate on behalf of the state and partly community-driven as a locallevel provider of social welfare and, increasingly, as the (state) mechanism of social control. Today Uzbek authorities claim that the mahalla reforms (the elevation of mahalla's social norms to law) have greatly facilitated citizens' self-government activities and provided mahalla with wider opportunities and autonomy. However, many Western scholars (For example Kamp 2004; Koroteyeva and Makarova 1998; Noori 2006; Sievers 2002) and human rights groups (Human Rights Watch 2003) maintain that mahalla reforms have a negative impact on the democratic developments in Uzbekistan. The central critique is based on the concern that mahalla, as a distributor of the state's social-welfare benefits, is the first place or instance where people encounter corrupted system in Uzbekistan (Human Rights Watch 2003; Kamp 2004; Koroteyeva and Makarova 1998; Micklewright and Marnie 2005). An-

9 Although Eric W. Sievers does not explicitly mention the impact of mahalla reforms on political stability in Uzbekistan, his study shows that mahalla, as a social-security network, ease the economic problems of their residents in the absence of a universal welfare state in post-independence Uzbekistan. See Sievers (2002), 91-158. 
other critique is centered on the argument that the state's legal interventions have transformed mahalla into extensions of authoritarian control (Human Rights Watch 2003; Noori 2006). Apparently, the case of mahalla appears to be an interesting case for studying the effects of the transition from "order without law" (the term is from Ellickson 1991) to "law from order" (the term is from Cooter 1997). In this regard, the next section of the paper will be devoted to studying the effects of legal interventions on mahalla with an effort to understand how the state and mahalla interact with each other.

\subsection{Legal intervention in mahalla}

Constrained by scarce financial resources and increasing inequality levels, Uzbekistan tried to reform its public-administration system with the aim of creating favorable conditions for stable nation-building processes in the transition period. In the same vein, the Uzbek government has revised its legal system and institutions in an effort to expand its reach both nationally and locally. As David Abramson notes, "beginning in the late 1980s and intensifying in the 1990s, the Uzbek mahalla became the centerpiece of a state-sponsored campaign to transfer responsibilities for welfare and other social services onto local shoulders" (Abramson 2000b. Constructing Corruption: Foreign Aid, Bureaucratization, and Uzbek Social Networks as quoted in Sievers 2002, 144). For a brief period during the first stages of the nation-building process, there was a widespread assumption that Uzbekistan would be able to build democratic institutions and market-based economy by revitalizing its pre-Soviet historical institutions and popular traditions. Accordingly, pre-Soviet mahalla institutions presented themselves as feasible solutions for promoting economic efficiency, social order and political stability. Thus, mahalla have become the focal point of all state and non-state functions (Sievers 2002).

Although the deployment of mahalla structures for politico-administrative purposes dates back to the Soviet years (Human Rights Watch 2003; Kassymbekova 2003; Masaru 2006; Noori 2006), as I demonstrate later, post-independence publicadministration reforms, namely mahalla reforms, have significantly differed from the technologies that were originally deployed by the Soviet authorities. While the Soviet legislation vaguely defined the legal status and functions of mahalla as local village councils, ${ }^{10}$ post-independence legislation largely strengthened the legal status of mahalla and defined them as citizens' self-government institution. Mahalla reforms have been implemented under the discourse of democracy and decentralization in the post-independence period. Obviously, the main rhetoric behind these reforms was to abandon the traditional communistic public-administration

10 According to Neema Noori (2006), the first legislation on the mahalla came in the 1920s; the main of aim of this legislation was to use mahalla for the modernization of Uzbek social life. The second Soviet legislation on mahalla in 1932 was concerned with the devolving state-service delivery to mahalla; mahalla were tasked to support local government functions. However, both legislations did not clearly specify the status of mahalla in the public-administration system. 
in which the public-administration system was centrally-planned. As citizen's local self-government institution, mahalla have been tasked to target social-welfare benefits, facilitate public administration and preserve political and social stability.

Today the term "mahalla" is commonly used in Uzbekistan to describe a neighborhood or local community which is mostly characterized by common traditions, language, religion and ethnic background. Everyone in Uzbekistan technically belongs to one mahalla (Sievers 2002). There are about 12,000 mahalla in Uzbekistan, and each mahalla might contain 150 to 1,500 households. On average, approximately 400 households reside in one mahalla (Micklewright and Marnie 2005, 431). The Mahalla Foundation, established in September $1992^{11}$, coordinates the activities of all mahalla throughout Uzbekistan. Mahalla, in both the historical and modern perspectives, represents a "clearly defined socio-demographic, cultural and spiritual entity, as well as an administrative-territorial one, in which people are united by traditions, customs and human, business and legal relationships" (Bektemirov and Rahimov 2001, 477). Mahalla bonds people based on the principle of common residence in a certain neighborhood with an established border. ${ }^{12}$ As Sievers (2002) noted, the most universal and remarkable aspect of mahalla is that no member of the mahalla is, for class, profession or religious reasons, excluded from community events and interactions. Mahalla is valued by most people as a social safety net embodying moral ideas of solidarity and mutual help (Louw 2007). Something analogous to mahalla might exist in other Eastern cultures, but what makes Uzbek mahalla unique is that it has received the legal status of a citizen's local self-government institute. As the primary self-government unit, mahalla exist throughout Uzbekistan today based on the principle of decentralization (Bektemirov and Rahimov 2001).

The Law on Mahalla $(1993,1999)$ defines mahalla as an "an independent activity of citizens, guaranteed by the Constitution and the Laws of the Republic of Uzbekistan, for the purpose of resolving issues of local importance according to their own interests and historical peculiarities, as well as to national traditions, spiritual values and local customs." ${ }^{\prime 3}$ Apparently, this definition implies that mahalla are non-governmental organizations, and they are not part of the system of public administration. Since mahalla is a new phenomenon to many Western scholars, the legal status of mahalla has been the object of intense discussions. The Mahalla Law defines mahalla as a non-governmental organization, but, at the same time, the Mahalla Law delegates some rights and obligations to mahalla which are reminiscent of

11 Presidential Decree of 12 September 1992 on the Creation of the Mahalla Foundation, Sharq So'zi, 13 September 1992.

12 See Local Government Situation and Development Prospects in the Countries of Central Asia. OSI/LGI Report (2002). Budapest.

13 Law on Mahalla, 1999, art.1. 
the functions of governmental agencies. ${ }^{14}$ Uzbek authorities proclaimed mahalla to be civil-society institutions, whereas the Western scholars and human-rights groups regard mahalla as extensions of authoritarian control at the local level (Human Rights Watch 2003; Kamp 2004; Noori 2006). Hence the conventional definitions of civil society that have a Western origin are largely irrelevant and inapplicable in the context of Uzbekistan. While Western-oriented values and beliefs on civil society promote individual opportunities and freedoms, the local understanding of civil society in Uzbekistan is largely based on the notion of collectivism and reciprocal relationships. ${ }^{15}$ In this regard, mahalla represents the local understanding of civil society in Uzbekistan or, as Abramson (2001) put it, "a civil society based on collective identities and the reciprocal relationships necessary to get things done." Mahalla also have informal information channels. In the absence of genuine and free mass media in Uzbekistan, mahalla, though informal, represent alternative sources of information. If some event happens that has nationwide importance, residents first get information from their informal mahalla channels, not from the formal mass media channels.

Mahalla are currently run by both formal (elected according to law) and informal leaders (informally chosen by residents). Prior to the legal intervention, mahalla were administered basically by three informal leaders, oqsoqol (whitebeard, informal leader of mahalla), ${ }^{16}$ boylar (wealthy residents in the community), ${ }^{17}$ and dasturhonchi (a woman leader). These informal leaders were basically responsible

14 Mahalla perform a wide range of state functions which were mainly implemented by specialized state agencies during the Soviet period. According to the Mahalla Law (1999), mahalla citizens' assemblies nominate the candidates for national and local elections; mahalla can give recommendations to residents on the organization of wedding ceremonies and other kinds of celebrations; mahalla can collect voluntary contributions from residents for the purpose of enhancing the well-being of mahalla; mahalla can demand of enterprises on its territory to provide an environmental report; mahalla facilitates the implementation of public policies; mahalla organizes the logistics of local visits of deputies of the parliament, regional, district and city councils; mahalla must report any illegal religious organization and assist state law-enforcement bodies; mahalla also facilitate the tax-collection process and the implementation of state-funded programs targeted to vulnerable issues, such as elderly care.

15 The mahalla has always been a place where rich and poor, ordinary people and functionaries, Uzbeks and other ethnic minorities, people with different religious background come together and discuss issues that are of mahalla significance.

16 Oqsoqol is usually an older male in a mahalla chosen by consensus from his generational group for his personal reputation, intelligence, honesty, personal influence and leadership skills. Although the Mahalla Law uses the terms "oqsoqol" and "rais" interchangeably, I prefer to use the term "oqsoqol" to refer to an informal leader of mahalla, whereas the term "rais" refers to formal leaders of mahalla which are elected according to the Mahalla Law.

17 In both historical and modern contexts, the wealthy have more prestige and authority within the community, due to their donations to most of the community projects, such as irrigation, asphalting of roads, building of mosques, community assistance to poor and vulnerable residents, etc. In comparison to others, wealthy residents usually contribute more to mahalla projects. Given this factor, wealthy residents have an equally influential role in the decision-making process in mahalla. 
for organizing wedding, circumcision and funeral ceremonies, they also mediated disputes between residents and organized hashar. ${ }^{18}$ However, after the adoption of the Mahalla Law in 1993 (and the subsequent revision of the Mahalla Law in 1999), the number of mahalla leadership has doubled. Under the Mahalla Law (1999), a chairman, rais, who is a salaried state employee, leads the mahalla through citizens' assembly/council ${ }^{19}$ together with a formal female leader of the mahalla women's committee. The citizens' assembly (fuqarolar yigini) is the supreme body of mahalla, which elects a chairman (rais), an executive secretary, an advisor and chairmen of the auditing and administrative committees of mahalla. Under the Constitution, the chairman (rais) of mahalla is elected for a term of 2.5 years. ${ }^{20}$ Residents over the age of eighteen are entitled to attend the citizens' assembly. Citizens exercise their right to self-governance by participating in the activities of citizens' assemblies. The citizens' assembly has the power to represent the interests of residents and make decisions on behalf of mahalla, which are effective on the respective territory. ${ }^{21}$ In turn, the citizens' assembly approves the members of the assembly council (kengash), which includes the chairman of the citizens' assembly, various advisors, chairmen of assembly commissions and the executive secretary. The citizens' assembly council implements the decisions of the citizens' assembly and carries out daily self-government activities of mahalla between sessions. ${ }^{22}$

The legal intervention has also empowered mahalla to implement the state's social-welfare legislation. In this sense, mahalla might look like parastatal organizations from the Western perspective, given the fact that they implement the state's social-welfare legislation. Social policy-makers in Uzbekistan found mahalla to be the most effective and credible mechanism to implement welfare programs, while the implementation of welfare legislation is mainly placed in the hands of specialized state agencies in the Western countries. For example, municipal social-welfare committees are responsible for the implementation of social-welfare programs in Sweden. Seemingly, social policy-makers in Uzbekistan assumed that mahalla-based targeting of welfare benefits (means testing) is fair and that the people who are in charge of means testing actually know what they are doing and care about getting the benefits to the people who need them. Although guidelines $(1994 ; 2002)$ of the Ministry of Labour and Social Protection provide detailed instructions considering the indicators of living standards, the guidelines do not specify the circumstances

18 Hashar is a community project, such as the cleaning of streets, the asphalting of roads, the construction of dwellings or mosques, the organization of wedding, funeral and circumcision feasts. During hashar, residents are expected to contribute to community projects with labor or monetary rewards.

19 Although the Mahalla Law stipulates that the mahalla rais is chosen by elections, this rule is rarely fulfilled in practice. In most cases, the local governor appoints the rais in an unstardardized way.

20 Article 105, supra note 7, Constitution of the Republic of Uzbekistan.

21 Articles 9, 10, Mahalla Law.

22 Article 10, Mahalla Law. 
in which the benefit should be awarded. In this regard, based on their local knowledge and standards, mahalla target social assistance and child benefits to the most needy families in the community. The mahalla council (kengash) can make a decision without much regard for objective criteria about which residents are entitled to receive benefits (Sievers 2002, 142). Therefore, mahalla have much discretionary power over whom to grant cases, and welfare benefit can be awarded to any household which "has sound reasons for receiving it." The final decision of the mahalla remains discretionary, and there is no appeal mechanism available (Micklewright and Marnie 2005).

\subsection{The effects of legal intervention}

American sociologist William Graham Sumner (1906) maintained that "the law must, regardless of the stage of societal development, reflect the mores of society in order to be an effective regulator of human behavior. As an instrument of social change, law can fulfill its proper role only if it conforms to the mores of a society." John Locke (1961) also argued in his book The Second Treatise of Civil Government that the state enforcement of social norms is more certain and secure than private enforcement, because a written law provides a canonical formulation of the underlying obligation. By passing the Mahalla Law, the government assumed that this law will make mahalla an even more efficient and legitimate institution in providing public goods to its residents. At the same time, the government tried to integrate mahalla into the public-administration system with the aim of promoting social order in an ethnically diverse society. Consequently, the official rhetoric behind the mahalla reforms was to promote citizens' involvement in policy-making through local governments. Following the reforms, mahalla have gained the legal status of a citizens' self-government institution. Mahalla has been announced as a national democratic institute which can facilitate democratic transformations in Uzbekistan. The architects of the Mahalla Law implicitly assumed that the legal intervention does not affect local autonomy and traditional functions of mahalla (Sievers 2002). However, as the Human Rights Watch Report (2003) demonstrates, legal intervention has considerably reduced the autonomy of mahalla. Sievers (2002) argues that excessive legal intervention might lead to an erosion of the traditional functions of mahalla, such as social insurance and dispute resolution.

Social policy-makers in Uzbekistan trumpet mahalla as an effective institution to discern those who are most in need of social-welfare benefits. Micklewright and Marnie (2005) observed that mahalla, despite an absence of a formal set of rules, delivers benefits much more frequently to the less well-off than to the better-off. On the other hand, as the Human Rights Watch Report (2003) indicates, sometimes mahalla committees use their discretionary power to pressure independent Muslims and women to change their behavior or to give up social assistance. In this context, Kamp (2004) claims that many mahalla committees probably do not have much incentive to be fair or accurate in means testing, but rather would have the 
incentive to prove that their relatives need benefits more than other people do ${ }^{23} \mathrm{Ko}-$ roteyeva and Makarova (1998) also argue that mahalla-based welfare distribution elicits irritating and frequent suspicions of corruption.

The adoption of the Mahalla Law has drastically increased the responsibilities of mahalla. Most of mahalla's informal functions have become a formal responsibility of mahalla. Now the violation of mahalla decisions is punishable by law. The law created parallel power structures within mahalla. In fact, the activities of mahalla are heavily influenced by the district and city administrative government authorities (hokimiyat), and in turn, they (hokimiyats) are directly accountable to the central government (Human Rights Watch 2003, 7). Sievers $(2002,119)$ also claims that despite the existence of elections, the district/city government is the actual power broker. Although the chairman and members of the mahalla are elected by mahalla residents, as the $\mathrm{Hu}$ man Rights Watch Report shows, the head of the administrative government (hokim) either nominates the candidates for elections or the election results must be approved by the administrative government authorities. In this regard, the current administrative structure of mahalla is likely based on the interplay between formal and informal leadership. Informal leaders of mahalla assume the informal leadership role in tandem with the formal mahalla leadership. This parallel power structure can be regarded as a form of mahalla resistance to the state arrogation (Sievers 2002, 121).

In this context, a number of studies demonstrate that it is becoming an increasingly difficult task to separate social norms of mahalla from its legal responsibilities, or mahalla from the state (Human Rights Watch 2003; Kamp 2004; Kassymbekova 2003; Noori 2006; Sievers 2002). Mahalla, in spite of the legal intervention, are still largely informal institutions which embody the features of self-autonomy and local governance. The norm classification system by Hyden and Svensson (2008) is a useful tool to understand the current formal and informal structures of mahalla (See Table 1). Through an understanding of the essential and accidental attributes of norms, it is possible to describe and categorize various norms operating in mahalla. According to Hyden and Svensson (2008), norms have three essential attributes: norms are behavioral instructions/imperatives (1), they are socially reproduced (2), and they represent the individual's understanding of surrounding expectations regarding their own behavior (3). Accidental attributes of norms include aspects like the presence of sanctions, the origin of the norm, the context or arena in which the norm is socially reproduced, if the norm is system-oriented or value-oriented, the internal functions and purposes of the norm. Finding the essences will be crucial when defining the norms whereas understanding the accidents will help to classify norms.

23 Eric Posner $(1996,178)$ claims that the delegation of power to an organization raises two kinds of problems for the state: first, the group's interests do not precisely reflect the state's; second, the group helps only its members. In this regard, it is difficult to measure the legal certainty and predictability when the application of the law is combined with decentralized decision-making. Micklewright and Marnie (2005) observed that due to a lack of official data, it is very hard to estimate whether or not mahalla-based targeting can facilitate an efficient and equitable implementation of social-welfare programs. 


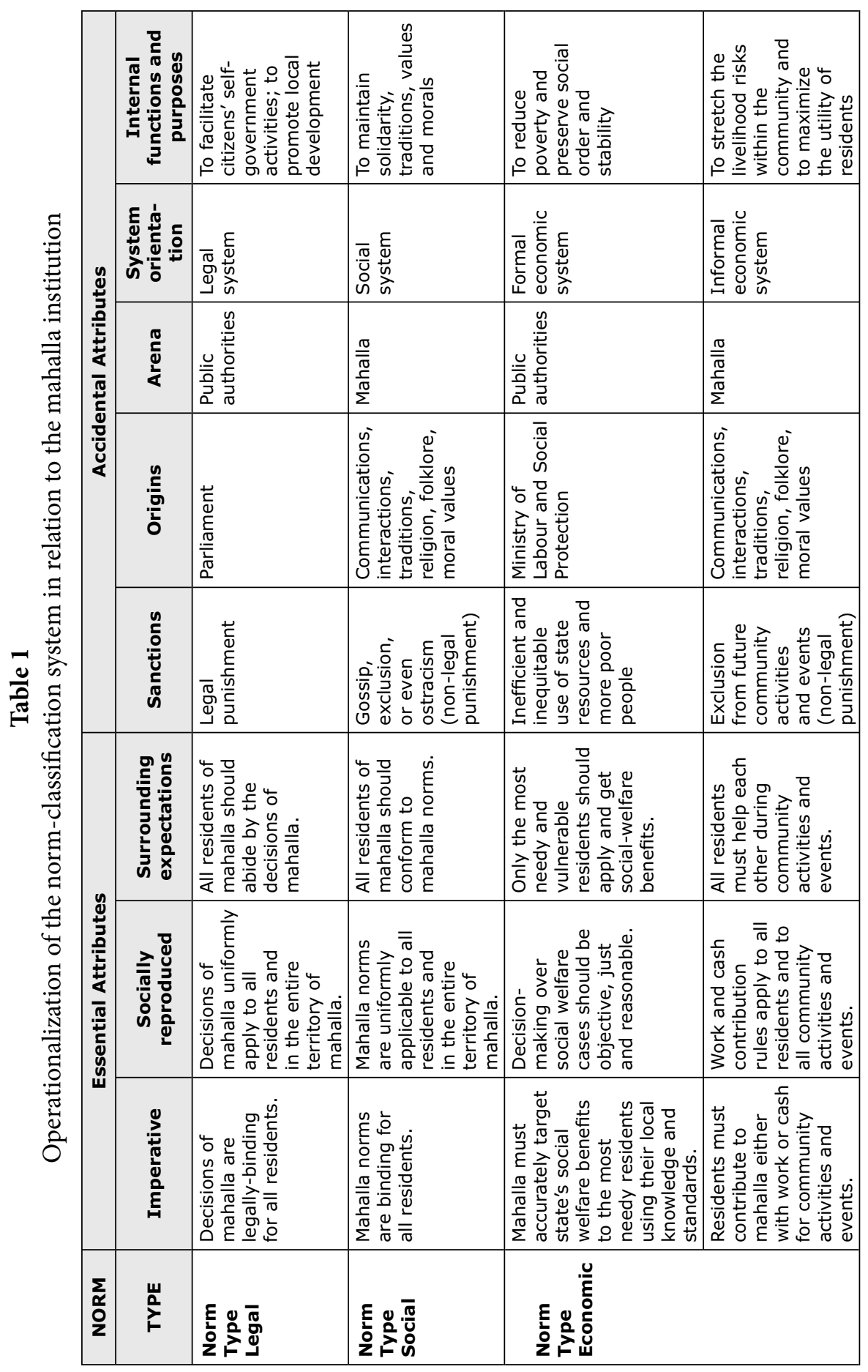




\begin{tabular}{|c|c|}
\hline 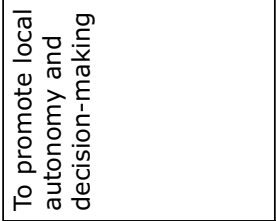 & 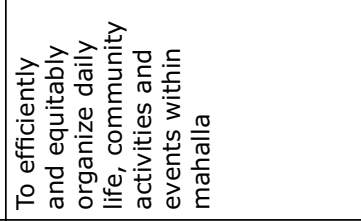 \\
\hline 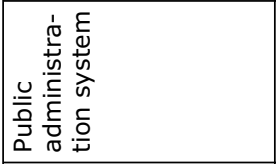 & 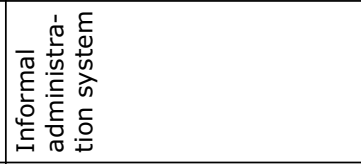 \\
\hline 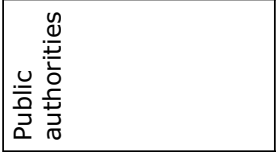 & $\begin{array}{l}\frac{\pi}{\bar{N}} \\
\frac{1}{\sqrt{0}} \\
\sum\end{array}$ \\
\hline & 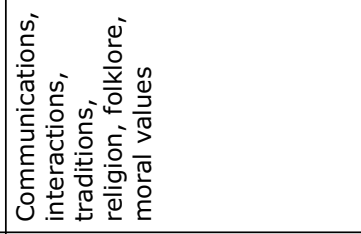 \\
\hline 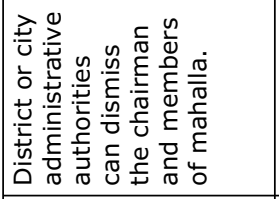 & 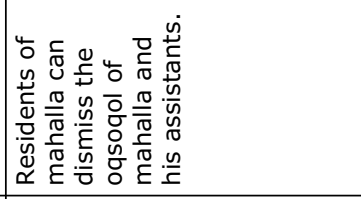 \\
\hline 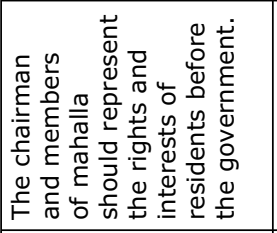 & 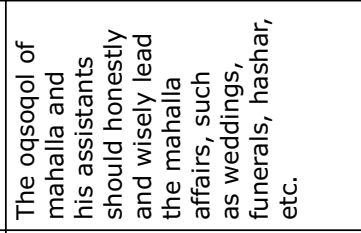 \\
\hline 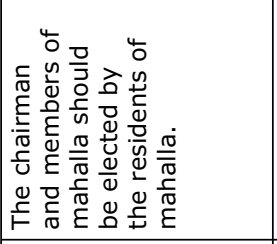 & 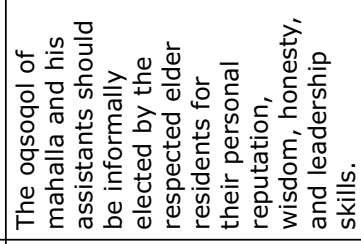 \\
\hline 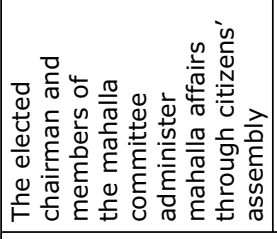 & 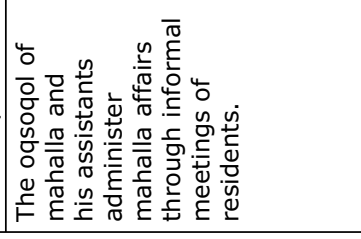 \\
\hline 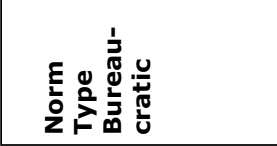 & \\
\hline
\end{tabular}




\section{Mahalla as the Welfare Pentagon}

Since their inception, mahalla have been very successful in maximizing the utility of their residents. The role of mahalla has considerably grown after the collapse of the Soviet Union, since newly-independent Uzbekistan could not afford a Soviet-type welfare system. As Sievers $(2002,103)$ noted, "the economic significance of mahalla has shifted from being a vehicle through which to amass additional or disposable wealth to a vehicle for basic survival." As a result of these dramatic changes, mahalla quickly assumed the functions of the welfare state and adapted to new economic conditions, thereby developing their survival mechanisms. Similarly, Seiple $(2005,251)$ describes mahalla as the place where group members look out for each other, collectively parenting their children, connecting friends and family to jobs, distributing funds to those in need and submitting to the judgment of elders. In this regard, mahalla replaced the state as the primary provider of social guarantees, and they provide extensive social services for community residents; mahalla provide both monetary and non-monetary (cash benefits and benefits-in-kind) types of welfare.

The welfare provision role of mahalla can be better explained by reference to the "Welfare Pentagon" model, which was developed by de Neubourg (2002). According to de Neubourg (2002), the Welfare Pentagon represents the five core institutions that households may use to meet their current and future needs in a given society: family, markets, social networks, membership institutions and public authorities (see Figure 1). Despite the historical and geographical differences, these institutions can be found in diverse appearances in all societies around the world. The access of households to the institutions and assets of the Welfare Pentagon varies across countries and over time. Public authorities (and partly the market), through various social-policy arrangements, are the most important players in the welfare provision in the West (especially in Nordic countries), while markets, family, membership institutions and social networks appear to be the largest sources of welfare in developing/non-industrial countries. Households use the institutions of the Welfare Pentagon in their survival strategy to generate income and to smooth consumption. Labor markets, product markets and capital markets enable households to trade and exchange in order to secure resources to satisfy their basic needs at a given time. Families, social networks and membership institutions ${ }^{24}$ tackle the livelihood risks through various mechanisms of solidarity. Public authorities, as the fifth corner of the Welfare Pentagon, can provide welfare to households by means of various welfare-state arrangements (pensions, child benefits, maternity benefits, social assistance, unemployment insurance and other forms of insurance), but also

24 Membership institutions are unions, mutual insurance companies, religious organizations, cooperatives or neighborhood associations, etc. In the case of mahalla, mosque and hashar (mutual assistance activity) can be regarded as membership institutions. 
indirectly by enforcing contracts through the judicial system, introducing legislation aimed at correcting market inequalities and many other public policies.

\section{Figure 1}

The Welfare Pentagon

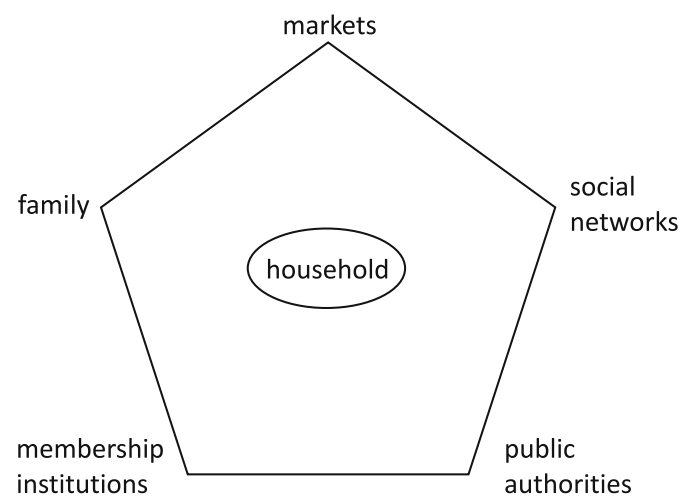

Source: de Neubourg (2002)

Post-Soviet mahalla include all five core institutions of the Welfare Pentagon: all five institutions contribute to the well-being of mahalla residents. Mahalla, by enforcing its social norms, stretch the livelihood risks within the community and catalyze these institutions to produce welfare. Social safety nets of mahalla are multidimensional. Mahalla can fulfill the functions of markets, provide public goods, implement state-welfare legislation and serve as a social network and membership institution. Most mahalla possess such public spaces as teahouses, markets, mosques, grocery stores and barbershops. Mahalla, especially in rural areas, have developed informal labor, product and capital markets. Most foreign businesses of Uzbekistan are carried out by a local mahalla-based group of traders and entrepreneurs. Most agricultural products are exported to Russia through these groups. ${ }^{25}$ Mahalla fulfill the function of a labor-recruitment agency by providing people with seasonal jobs. Informal channels of mahalla are so extensive and comprehensive that residents can quickly get information about available job opportunities. Mahalla-based entrepreneurs, traders and brokers very often provide their co-residents with temporary jobs, especially during summer and autumn periods. Mahalla is also a place where people get information about possible job opportunities in Russia and Kazakhstan. Therefore, most Uzbeks succeed in finding a job in Russia

25 Groups of traders are especially active in the Ferghana valley. These groups mainly buy agricultural products, such as cucumbers, grapes, peaches, apples, etc. from mahalla residents for relatively higher prices and export them to Russia. The local population calls these groups "rossiychilar" (group of traders that export Uzbek agricultural products to Russia). 
and Kazakhstan due to their mahalla networks. Women derive income by sewing clothes for residents of mahalla. Residents of mahalla also exchange various goods and products among each other. In this regard, mahalla, serving as local markets, provide a large number of job opportunities and facilitate the income-generating strategy of their residents.

Family, social networks, mosque and hashar (as a membership institution) are important sources of welfare in Uzbek mahalla whereas these institutions have a relatively limited role in most Western countries. Mahalla residents often rely on their families, social networks, mosque and hashar to meet their livelihood needs. Few weddings, emergency medical operations, university matriculations, house constructions or funeral ceremonies occur in the life of the typical mahalla resident without some community financial support (Sievers 2002, 129). According to mahalla norms, residents should make some financial contribution to wedding expenses when they attend wedding feasts. Such a type of community assistance considerably lessens the burden of weddings on families.

Over the centuries, mahalla developed tradition of mutual assistance, 'hashar' which can be regarded as a well-established social norm. Under the absence of any legal mechanisms, mahalla residents cooperate with each other by providing labor for the construction of houses, for the preparation of the logistics of wedding and funeral ceremonies and many other informal services that are necessary for human livelihood. After the adoption of the Mahalla Law, the hashar tradition has become a legal obligation. The formal chairman and members make use of hashar to encourage residents to maintain the cleanliness of streets and gutters and to improve the appearance of their mahalla on the eve of national celebrations and state holidays (ibid.). Residents gain more by engaging in mahalla activities, since the collective action lowers the transaction costs. In this sense, Posner (1996) claims that an actor will choose cooperation over independent action only if the value of the benefits exceeds the cost of cooperation. Mahalla norms encourage cooperation and solidarity and discourage uncooperative behavior. Residents who defect from mahalla norms may face non-legal sanctions, such as exclusion and ostracism. These factors seem to explain why mahalla are so successful in providing alternative sources of welfare.

Moreover, mahalla lower the transaction costs for their residents by rendering non-compensated services to the elderly and sick, mediating domestic-violence and divorce cases and resolving various disputes between residents. Mahalla also pressure more wealthy residents to share some of their wealth with the wider community (Bektemirov and Rahimov 2001). As described by Sievers (2002, 102), on the eve of national holidays, mahalla residents collectively clean public spaces, cook 
national desserts for distribution to all mahalla residents and often provide small presents to poorer residents. ${ }^{26}$

After gaining independence, mahalla were empowered to allocate social-welfare benefits to the most needy in the community. These benefits are fully financed by the government. Through a means-testing method, mahalla provide welfare benefits to the least well-off residents. Even though the amount of the benefit is very small, it plays a crucial role in the survival strategy of people, especially in rural areas. In this regard, mahalla include the fifth element of the Welfare Pentagon public authorities.

As was shown above, mahalla play an essential role in the survival strategy of their residents by providing both formal and informal social safety nets. Mahalla have become an integral part of Uzbek society, since they represent all five core institutions of the Welfare Pentagon. Similarly, mahalla has assumed the basic functions of the welfare state, which resembles the Western welfare states. One may wonder if mahalla can be called the "fourth type of welfare state regime." ${ }^{27}$ In this context, mahalla can be regarded as a "hybrid institution" that represents both formal and informal elements of the Welfare Pentagon. Given the effect of welfare on social control, one may guess how influential mahalla are in promoting social order and political stability and why the Uzbek government is so keen to intervene. Since mahalla serve as informal labor, product and capital markets, since mahalla provide welfare for residents through family, social networks, mosque and hashar (membership institution), and since mahalla distribute the state's welfare benefits, mahalla can be regarded as both formal and informal mechanisms of social control that create stable conditions for a smooth functioning of the political system in Uzbekistan.

\section{Mahalla as a system of social control}

Today most Uzbeks get their sense of identity through their mahalla. Mahalla play an enormous role in fostering the cultural attitude of their residents. As Sievers (2002) observed, most Uzbeks reject the possibility of excluding themselves from a mahalla. There are a lot of Uzbek sayings regarding the importance of mahalla in people's lives. Vago $(2009,19)$ claims that in a small, traditional and homogeneous society, behavioral conformity is ensured by social norms which are supported by traditions. Social control in such a society is mainly established through informal

26 Navruz is one of the Uzbek national holidays that mobilize people to clean mahalla, to cook desserts and to take care of poorer residents.

27 Danish sociologist Gøsta Esping-Andersen describes three types of welfare state regimes (liberal, conservative and social democratic). However, Esping-Andersen's typology only describes the Western world of welfare capitalism whereas the welfare systems of the developing world are mostly based on informal welfare arrangements. In this regard, I dare to call mahalla the fourth type of welfare-state regime. See Esping-Andersen (1990). 
control mechanisms, such as gossip, ridicule or humiliation. In this regard, mahalla norms regulate and touch upon even the strictly private spheres of residents' lives, ranging from dressing styles to marital relations. The failure to comply with mahalla norms might lead to non-legal sanctions, and therefore, every resident tries to conform to norms established within the mahalla. The threat of exclusion deters residents from violating mahalla norms, and therefore, social control in mahalla is dependent on individuals' self-sanctioning. ${ }^{28}$

Gossip is one of the strongest non-legal sanctions in mahalla. Gossip is an instrument to use social influence to guide individual actions, especially in densely populated areas. Since most mahalla residents are highly concerned about the public opinion, they always try to avoid people's gossip. In that sense, gossip is also one of the strongest non-legal mechanisms that maintain cooperative behavior among the residents. According to mahalla norms, every mahalla member is expected to publicly mark births, male circumcision, weddings and deaths with some kind of celebration. Despite the high costs, every member of mahalla tries to conform to this norm. Residents who fail to mark any of those celebrations would be excluded from future mahalla celebrations. Social norms greatly contribute to social solidarity and order within mahalla. In this regard, Posner (2002) asserts that people, despite the high costs, give signals to each other in order to show that they belong to the good type and they are cooperative partners. Signaling is the expression of conformity to social norms. Good types care more about future payoffs that are lost if the cooperation fails.

Mahalla norms even control the family issues of residents. According to mahalla norms, the youngest son inherits the family home, and older sons are supposed to move out of the house. But, in turn, the youngest son must take care of his parents when they grow old. Seemingly, norms somehow establish an informal contract between children and parents. Mahalla will keep a close eye on the enforcement of this informal contract. In cases of defection, deviants face non-legal sanctions of mahalla, such as gossip, exclusion or even ostracism. Deviants are regarded as uncooperative partners in the community. From a social-policy perspective, mahalla might look like very attractive institutions given their capacity to cater for old people, whereas the elderly care is the ultimate responsibility of government in many Western countries.

28 Although non-conformity does not lead to any legal sanctions, every resident tries to conform to the established rules of mahalla, because mahalla can impose non-legal sanctions on deviants. The mahalla system enables people to access various welfare pentagon institutions, but at the same time, it limits individual autonomy and privacy. In this sense, Posner argues that, "wherever interaction is continual, dense and valuable to participants, distinctive patterns of behavior emerge. When deviations from these patterns provoke non-legal sanctions, we say that the patterns are social norms. Social norms both create options and suppress them." See Posner (2002). 
Posner (1996) pointed out that when dispute arises between the members of a solidary group, norms and non-legal sanctions generally resolve disputes by allocating risks and specifying means of resolution. Mahalla, in this sense, mediate the conflictual relations between residents by using their norms and non-legal mechanisms of dispute resolution. In most cases, the informal leader (oqsoqol) of mahalla mediates the disputes between neighbors, adjudicates domestic violence and divorce cases. After the Mahalla Law, the formal leader of the mahalla committee (a legally elected leader) now also has the authority to address these issues. As described by Sievers (2002), since mahalla residents are usually involved in lifelong contact, the costs of court proceedings outweigh the benefits. Mahalla's informal dispute-resolution system is effective in the sense that it does not use adversarial methods while the legal mechanisms are lacking in this regard. Mahalla norms also condemn those residents who use legal means of dispute resolution. Residents who turn to courts are regarded as uncooperative partners. Therefore, mahalla residents rarely turn to courts and law enforcement agencies for the resolution of their disputes.

Mahalla norms regarding the relationship between spouses and bride and mother-in-law also cause concern. Mahalla norms promote the patriarchal relations in the family by encouraging a submissive role for women in the family. Mahalla norms also strictly regulate the power relations between mother-in-law and daughter-in-law. Mahalla norms establish that the daughter-in-law should obey her mother-in-law. Consequently, many human rights NGOs and feminist movements are highly critical of the domestic-violence cases within mahalla. Particularly, mahalla norms place women in an unfavorable position (Human Rights Watch 2003). Given the fact that mahalla norms favor patriarchal relations, the state's legal intervention is necessary, especially in cases of domestic violence. To address these problems, the public authorities intervened into mahalla by establishing a women's committee in each mahalla, but this strategy turned out to be ineffective due to the lack of support from social forces. Similarly, Hyden $(2008,149)$ claims that legal norms have to compete with norms already existing in society. Mahalla norms are sometimes more powerful than the legal norms.

Therborn $(2002,871)$ claims that institutions should be regarded as delimited complexes of norms which include constitutive norms of conduct, norms of distribution and regulative norms of contribution/execution. The norms of an institution may be formal or informal, explicit or implicit. These institutional norms are enforced by the systems of sanctions. Likewise, mahalla impose a wide range of non-legal sanctions on those residents who fail to conform to the norms of mahalla. Under mahalla norms, each resident is expected to contribute work and services during hashar, wedding and funeral ceremonies. The free-riding problem almost does not exist in this case, since the transaction costs of information is very low due to heavy social interactions and integration in mahalla. 
The adoption of the Mahalla Law has also increased the scope of mahalla's social control activity. Mahalla now can also use legal sanctions to influence the behavior of their residents. In this respect, mahalla can effectively control the behavior of their residents through social norms, law and welfare. The presence of both legal and non-legal sanctions enables mahalla to suppress anti-social behavior and promote pro-social behavior. The cost of anti-social behavior is very high in the mahalla system, due to the fact that deviants may not be able to access the welfarepentagon institutions of mahalla. Given the fact that they represent heavily integrated communities, mahalla can be regarded as a comprehensive system of social control, where the formal (governmental) and informal (societal) mechanisms of social control come to interplay. In this regard, Robert Ellickson's (1991) concept on "elements of a comprehensive system of social control" is relevant for explaining the social-control element of mahalla. Ellickson (1991) distinguishes five controllers that may be sources of both rules of behavior and sanctions that support those rules. The five controllers consist of - the actor himself, the person acted upon, social forces, non-governmental organizations and the government. These five controllers impose the following five sanctions to enforce the rules of behavior - self-sanctions, personal self-help, vicarious self-help, organization enforcement and state enforcement. Table 2 summarizes how social control labor is distributed within various controllers in mahalla.

Table 2

Mahalla as a System of Social Control. Source: Ellickson $(1991,131)$

\begin{tabular}{|c|l|l|l|l|}
\hline No. & \multicolumn{1}{|c|}{ Controller } & \multicolumn{1}{|c|}{ Rules } & \multicolumn{1}{|c|}{ Sanction } & \multicolumn{1}{|c|}{$\begin{array}{c}\text { Combined } \\
\text { system }\end{array}$} \\
\hline 1 & Resident & Personal ethics & Self-sanction & Self-control \\
\hline 2 & Family & $\begin{array}{l}\text { Contracts } \\
\text { (informal) }\end{array}$ & Personal self-help & $\begin{array}{l}\text { Promise-enforced } \\
\text { contracts }\end{array}$ \\
\hline 3 & $\begin{array}{l}\text { Informal leader } \\
\text { (oqsoqol) and } \\
\text { residents of } \\
\text { mahalla }\end{array}$ & Social norms & Vicarious self-help & Informal control \\
\hline 4 & $\begin{array}{l}\text { Formal leader of } \\
\text { mahalla (rais) }\end{array}$ & $\begin{array}{l}\text { Organization rules } \\
\text { (Mahalla law and } \\
\text { social norms) }\end{array}$ & $\begin{array}{l}\text { Organization } \\
\text { enforcement }\end{array}$ & $\begin{array}{l}\text { Organization } \\
\text { control }\end{array}$ \\
\hline 5 & $\begin{array}{l}\text { Government } \\
\text { (through law- } \\
\text { enforcement } \\
\text { bodies) }\end{array}$ & Mahalla law & State enforcement & Legal system \\
\hline
\end{tabular}




\section{Conclusion}

The state's legal intervention has greatly expanded the scope of the social control function of mahalla. At a quick glance, mahalla appear to be universal institutions, since they can provide public goods, reduce crime rates, offer alternative dispute resolutions, act as agents against the radical Islamists and preserve Uzbek cultural values. As the study showed, the public-administration reforms transformed mahalla into "hybrid" institutions, as they are now charged with enforcing both the law and social norms. Mahalla has become a place where initial interaction between the individual and the government occurs. Today public authorities in Uzbekistan claim that mahalla reforms have greatly improved the self-governance activities of citizens. As they further claim, the mahalla represents the National Democratic Institute, since it operates independently and is not a part of the local government system. However, these claims represent the mythological impact of legal interventions on mahalla. As the findings of this paper indicated, the principle of self-governance of mahalla is rarely fulfilled in practice. Conversely, legal interventions have transformed mahalla into a system of social control. In this regard, the state's legal intervention into mahalla can be seen as an attempt of Uzbek authorities to harness the social control power of mahalla for meeting political instabilities in the transition period.

Despite the state's legal interventions, mahalla retained their informal role and structures, as the presence of the parallel power structure shows. Informal economic activities are still widespread in mahalla. The state's legal interventions failed to mirror the actual functions and purposes of mahalla norms. Mahalla ultimately rely on social norms to preserve their solidarity, traditions, values and morals whereas the law mainly strives to use mahalla as a social control mechanism by integrating them into the system of public administration. As Posner $(1996,135)$ pointed out, the interaction between law and non-legal sanctions occurs not in a uniform and predictable way, but in a rather complex and unforeseen way. Every legal obligation provides a room for abuse. The effect of legal intervention depends on such characteristics as the political and economic system of the country. Due to the strength of social norms within mahalla, the outcome of the legal intervention became unpredictable, since the local knowledge, standards, traditions and values had influenced the application process. Given the fact that Uzbekistan has recently emerged from the central planning, the legal intervention provided expanded opportunities for corruption and authoritarianism. These are the real effects of legal interventions on mahalla. Unfortunately, legal interventions have limited the autonomy of mahalla, thereby making them extensions of authoritarian control.

As the study demonstrated, debates within Western academic and policy communities mainly see mahalla as an instrument of abuse or extension of authoritarian control by referring to its social control function. However, these debates are centered on only one side of the coin; they are predominantly based on Western val- 
ues and largely ignore local conditions and social norms of Uzbek society, which are realized in the mahalla system. As Starr (2005) noted, democracy cannot be built in Central Asia in the absence of key reforms, particularly at the local level. Consequently, people obey laws that reproduce social norms and are prone to disobeying laws that are not compatible with social norms (Cooter 1996). Mahalla, owing to their norm enforcing capacity and welfare provision function, can potentially promote the law-obedient cultural attitude in the society. Accordingly, this study suggests that any attempt at democratization of Uzbekistan should be aware of the fact that mahalla are plastic institutions: they can either facilitate democratic reforms or impede their implementation. In this regard, mahalla can be places of democratic involvement or sites of authoritarianism. It is the public administration system that determines the final outcome.

\section{References}

Abramson, D. M. 2001. "Identity Counts: The Soviet Legacy and the Census in Uzbekistan." In D. Kertzer and D. Arel (eds). Census and Identity: The Politics of Race, Ethnicity, and Language in National Censuses. Cambridge: Cambridge University Press, 186-199.

Abramson, D. M. 2000a. “Socialism's Bastard Children." PoLAR 23, 49-64.

Abramson, D. M. 2000b. Constructing Corruption: Foreign Aid, Bureaucratization, and Uzbek Social Networks. Unpublished paper presented at Harvard University. Available at http://turkmeny.h1.ru/cas/abramson.html (Last accessed 25 April 2011).

Bektemirov, K. and E. Rahimov. 2001. "Local Government in Uzbekistan." In V. M. Popa (ed.). Developing New Rules in the Old Environment. Budapest: LGI/OSI Europe, 469-520.

Clarke, H. L. 1999. "An American View of Uzbekistan." Central Asian Survey 18 (3), 373-383.

Cooter, R. D. 1997. "Law from Order: Economic Development and the Jurisprudence of Social Norms." John M. Olin Working Papers in Law, Economics, and Institutions 96/97 (4), 1-33.

Cooter, R. D. 1996. "The Rule of State Law and the Rule-of-Law-State: Economic Analysis of the Legal Foundations of Development." Paper presented at the Annual World Bank Conference on Development Economics.

Coudouel, A. and S. Marnie. 1999. "From Universal to Targeted Social Assistance: An Assessment of the Uzbek Experience." MOCT-MOST: Economic Policy in Transitional Economics 9 (4), 443-458. 
de Neubourg, C. 2002. "The Welfare Pentagon and the Social Management of Risks." In R. Sigg and C. Behrendt (eds). Social Security in the Global Village. New Brunswick: Transaction Publishers, 313-331.

Diamond, L. 1994. "Rethinking Civil Society: Toward Democratic Consolidation." Journal of Democracy 5 (3), 14-15.

Ellickson, R. C. 1991. Order Without Law: How Neighbors Settle Disputes. Cambridge, Mass: Harvard University Press.

Erdem, E. 2006. Political Salience of Ethnic Identities: A Comparative Study of Tajiks in Uzbekistan and Kurds in Turkey. Ph.D. dissertation, Stanford University Retrieved 12 October 2010 from Dissertations \& Theses: A\&I. (Publication No. AAT 3235214).

Esping-Andersen, G. 1990. The Three Worlds of Welfare Capitalism. Cambridge: Polity Press.

Fane, D. 1996. "Ethnicity and Regionalism in Uzbekistan: Maintaining Stability through Authoritarian Control." In L. Drobizheva, R. Gottemoeller, C. M. Kelleher and L. Walker (eds). Ethnic Conflict in the Post-Soviet World: Case Studies and Analysis. Armonk, NY: M. E. Sharpe, 271-302.

Gleason, G. 2001. "Asian Values' and the Democratic Transition in Central Asia." Harvard Asia Quarterly 5 (1).

Human Rights Watch. 2003. From House to House: Abuses by Mahalla Committees. Vol. 15. New York: Human Rights Watch.

Hyden, H. 2008. "Putting Law in Context: Some Remarks on the Implementation of Law in China." In H. Hyden and P. Wickenberg (eds). Contributions in Sociology of Law: Remarks from a Swedish Horizon. Lund: Media-Tryck Sociologen, $147-176$.

Hyden, H. and M. Svensson. 2008. "The Concept of Norms in Sociology of Law." Scandinavian Studies in Law 53, 15-32.

Ilkhamov, A. 2007. "Neopatrimonialism, Interest Groups and Patronage Networks: The Impasses of the Governance System in Uzbekistan." Central Asian Survey 26 (1), 65-84.

Kamp, M. R. 2004. "Between Women and the State: Mahalla Committees and Social Welfare in Uzbekistan." In P. J. Luong (ed.). The Transformation of Central Asia: States and Societies from Soviet Rule to Independence. Ithaca: Cornell University Press, 29-58.

Kassymbekova, B. 2003. "Uzbekistan's Mahalla: A Democratic Tool for Authoritarian Rule." Central Asia-Caucasus Institute Analyst 19 November. Available at http://www.cacianalyst.org/?q=node/1659 (Last accessed 14 October 2010). 
Koroteyeva, V. and E. Makarova. 1998. "The Assertion of Uzbek National Identity: Nativization or State Building Process?” In T. Atabaki and J. O'Kane (eds). Post-Soviet Central Asia. New York: I. B. Tauris.

Locke, J. 1961 [1690]. The Second Treatise of Civil Government. Ed. by Thomas I. Cook. New York: Hafner.

Louw, M. 2007. Everyday Islam in Post-Soviet Central Asia. Central Asian Studies Series. London: Routledge.

Masaru, S. 2006. "The Politics of Civil Society, Mahalla and NGOs: Uzbekistan." In I. Osamu and U. Tomohiko (eds). Reconstruction and Interaction of Slavic Eurasia and Its Neighboring Worlds. Sapporo: Slavic Research Center, Hokkaido University, 335-370.

Melvin, N. J. 2000. Uzbekistan: Transition to Authoritarianism on the Silk Road. Amsterdam: Harwood Academic.

Micklewright, J. and S. Marnie. 2005. “Targeting Social Assistance in a Transition Economy: The Mahallas in Uzbekistan." Social Policy and Administration 39 (4), 431-447.

Noori, N. 2006. Delegating Coercion: Linking Decentralization to State Formation in Uzbekistan. PhD Dissertation. Columbia University, New York.

Posner, E. A. 2002. Law and Social Norms. Cambridge, Mass: Harvard University Press.

Posner, E. A. 1996. "The Regulation of Groups: The Influence of Legal and Nonlegal Sanctions on Collective Action." University of Chicago Law Review 63, 133-198.

Ruziev, K., D. Ghosh and S. C. Dow. 2007. "The Uzbek Puzzle Revisited: An Analysis of Economic Performance in Uzbekistan since 1991.” Central Asian Survey $26(1), 7-30$.

Seiple, C. 2005. "Uzbekistan: Civil Society in the Heartland." Orbis (Spring 2005), 245-259.

Seligman, A. B. 1992. The Idea of Civil Society. Princeton: Princeton University Press.

Sievers, E. W. 2002. "Uzbekistan's Mahalla: From Soviet to Absolutist Residential Community Associations." Chicago-Kent Journal of International and Comparative Law 2, 91-158.

Spechler, M. C. 2000. "Uzbekistan: The Silk Road to Nowhere." Contemporary Economic Policy 18 (3), 295-303.

Starr, F. S. 2005. "Partnership for Central Asia." Foreign Affairs 84 (4), 164-178. 
Sumner, W. G. 1906. Folkways: A Study of the Sociological Importance of Usages, Manners and Customs, Mores and Morals. Boston, MA: Ginn.

Therborn, G. 2002. "Back to Norms! On the Scope and Dynamics of Norms and Normative Action." Current Sociology 50 (6), 863-880.

Vago, S. 2009. Law and Society. $9^{\text {th }}$ edn. Upper Saddle River, N. J: Pearson Prentice Hall. 